\title{
STATE MUNICIPAL LEAGUE MEETINGS ${ }^{1}$
}

\author{
BY WILLIAM PARR CAPES ${ }^{2}$ \\ Albany, N. Y.
}

$\mathbf{I}^{\mathrm{P}}$

F ORGANIZATION and co-operation will wipe out the stigma which has been placed upon American municipal government, we are in a fair way to make the city the most efficient unit of our government, for we are rapidly assembling and setting up the machinery which is linking together all American municipalities into one compact working force. We at least are determined to give the theory of co-operation a fair trial, and whether it fails or not we can never be accused by future generations of procrastination. Its success, however, is already being indicated by the results of the labors of the various organizations and the effects of these results on individual municipalities.

During the past year the mobilization of municipal forces in the United States has gone steadily forward until now we have fifty municipal leagues -national, state, inter-state and intra-state. The activity of this organized force is now a prominent factor in the effort underway in all sections to raise the standard of municipal service.

Our municipal organization is not yet complete, but the progress we have made in the last seventeen years has been remarkable. The United States to-day has three national municipal organizations and Canada one. ${ }^{3}$ Thirty-two states have organized their municipalities into leagues or kindred bodies." With the exception of the New England states all sections of the United States have been quite thoroughly organized, those states which have not yet organized being scattered. But even in some of these the seed of co-operation has already been planted by the organization of either inter-state or intra-state associations. ${ }^{5}$ Of the fifty organizations now devoting their time and effort exclusively to city welfare, five were established during the last year, the Cloverland association, the leagues of New Jersey, North Idaho and New Mexico and the

${ }^{1}$ See National Municipai Review, vol. v, p. 66.

2 Secretary, New York state conference of mayors and other city officials.

${ }_{3}$ The National Municipal League, the League of American Municipalities, the American Society for Municipal Improvement and the Union of Canadian Municipalities.

'Indiana, North Carolina, Texas, New York, South Carolina, Alabama, Ohio, Mississippi, Louisiana, North Dakota, Colorado, Tennessee, Arkansas, Kentucky, Massachusetts, Utah, Michigan, Montana, Illinois, Missouri, Kansas, Connecticut, New Jersey, Nebraska, California, Iowa, Minnesota, Oklahoma, Washington, Wisconsin, Virginia, New Mexico.

- Association of commission-governed cities of South Dakota, league of third class cities in Pennsylvania, North Idaho municipal league, the mayors' association of the South Atlantic and Gulf states, Cloverland association of municipalities embracing the cities of upper Michigan and the league of Northwest municipalities. 
mayors' association of the South Atlantic and Gulf states. Canada has nine provincial leagues. All national bodies are active and the majority of the state and provincial leagues are alert and aggressive to help their cities. Only a few have not yet realized their opportunity. To complete our plan we need to prod these, to organize the cities in the few states which have no leagues and either to establish or to designate a central co-ordinating body which will act as a clearing house for all the organizations, especially the state bodies.

The general work of the organizations during the year has been about the same as in previous years, with the exception that here and there some extraordinary activity has been undertaken to meet some exceptional or local condition. All have held annual meetings at which almost every municipal activity and various phases of each have been discussed by experts and city officials. The reports of the committees working during the year on particular municipal problems have been received and acted upon. Legislation to meet municipal needs has been drafted and advocated, and some has been enacted into laws. The leagues have taken. both the offensive and the defensive in their legislative work, and their effort to defeat objectionable legislation has been quite as important as. the remedial legislation they have sought. It has also been more successful.

Most of the leagues have issued printed reports of their annual meetings and these have increased the volume of the municipal library which these organizations are gradually building up in America. Some leagues have regular publications, Minnesota being added to this list during the year. These are Wisconsin, Minnesota, Washington, Texas, California, Carolina, Louisiana, Kansas, Iowa and New York and the Union of Canadian Municipalities and the National Municipal League. Two others contemplate the establishment of publications this year.

In addition to the propaganda and legislative work, sixteen leagues either have maintained bureaus of information or have co-operated with some university in operating such an institution. These are the leagues in California, Illinois, Iowa, New York, Kansas, Louisiana, Michigan, Nebraska, New Jersey, Texas, Washington, Northwest municipalities, Wisconsin, Minnesota and the League of American Municipalities and the National Municipal League. New Jersey's bureau was established during the year, and the unique experiment begun in 1915 by the New York state conference of mayors and other city officials has been declared by the cities in that state to be a success. The state bureau of municipal information, which the empire state cities established to test the practicability of a co-operating plan of obtaining municipal data, has, therefore, become a permanent institution and is now being operated on an extensive scale. This is significant, for New York has demonstrated that cities will liberally use and support an institution of this kind, and that a bureau 
exclusively for the use of city officials can be made to stand on its own feet without outside support. The empire state cities have blazed an important trail. Oklahoma is starting the same way as did New York. The president, vice-president and secretary of that western league have perfected plans to make a tour of the cities of the state this year for the purpose of studying municipal conditions and gathering data for the establishment of a bureau of information.

The discussions at the annual meetings of the organizations have made available a vast amount of valuable data. A review of these and a comparison with the work of previous years shows that the variety of subjects and phases of general problems about which cities are thinking are increasing. Several new problems were added to the programs of the leagues last year, among them being proportional representation, traffic regulations, civil service and fire insurance rates. Each of these subjects has been discussed by one or two leagues in the past, but during 1916 consideration of them became quite general.

In almost every section of the country seven municipal problems have been discussed within the year. These are paving and paving materials, city planning, public health, taxation and assessment, home rule and municipal accounting and financing. During 1916 particular attention was given to paving, public health and taxation problems. A most pronounced gain in popularity was made by city planning. The western and some of the southern cities still continue to lead in the discussion of municipal ownership and public utility rates.

At least four states, Missouri, Wisconsin, Michigan and North Carolina, are studying commission government and have discussed this subject at their annual meetings. Nearly all of the Canadian organizations and all of the national organizations in the United States have considered the several forms of government under which cities are now working, particularly the commission and the commission-manager.

Home rule still occupies a prominent part of the discussion in Missouri, New Jersey, Michigan, Indiana, Iowa, Illinois and New York. And, judging by the legislation sought by leagues, the subject should receive serious consideration in several other states. When cities have to seek legislative authority to build stockades on municipally owned property outside their limits, it is about time that they thought about increasing their powers by constitutional amendment. New York again asked for legislative approval of a home rule constitutional amendment and failed. Its sponsors, however, were encouraged by the popular support which the measure received. Plans have been completed to renew the campaign this year.

Municipal accounting and financing are live problems in every state, but constructive work has been undertaken during the year in Missouri, Minnesota, Oklahoma, Idaho, California, Iowa, Kansas, New York, and 
Wisconsin. Uniform accounting systems and uniform bond laws are the remedial measures now being sought, New York, Kansas and Wisconsin being interested in bond legislation and several states in uniformity in accounting. The state comptroller, co-operating with the New York conference, perfected during the year an accounting system for the third class cities in that state, and he is now installing the system in the forty-eight municipalities in that class. When this work is completed all empire state cities, with the exception of the three first class municipalities, New York, Buffalo and Rochester, will be working under approved uniform systems, as a uniform plan is already in effect in the second class cities.

The national and state leagues have not been far behind the few progressive American cities which are investigating the practicability of the activated sludge method of sewage disposal. The American Society of Municipal Improvements had an exhaustive discussion of the process at its recent annual meeting. The leagues of Texas, California, Illinois and New York have also considered the plan and other recent developments in sewage disposal. An unique movement in connection with the sewage disposal problem was undertaken during the year by the Iowa league. As a result there has been established a league of American cities having sewage disposal plants to combat the claims for royalty on the septic process of disposal.

One of the newer subjects that is now commanding the attention of cities is the regulation of motor and other traffic. The New York state cities, through their conference, have decided to ask the legislature for a uniform code of regulations. The proposed code has been drafted by the state bureau of municipal information. The American Society of Municipal Improvements and the California league have also developed an interest in the problem.

In reviewing the reports of the year's work the special efforts that most of the leagues have made to strengthen their organizations and to popularize co-operative municipal work cannot escape notice. Most of the leagues report an increase in membership and financial support and at least eight have attempted to convince the public of the value of municipal organization and co-operation.

While consideration has been given to peculiar conditions in Canadian cities resulting from the war, it was not so pronounced during the last year as in 1915. All of the municipal organizations in Canada have resumed consideration of the general problems, particularly of forms of government. One feature of all the annual meetings, however, has been the advocacy of municipal preparedness, indicating the farsightedness of the Canadian cities. If this campaign is continued as vigorously as it has been begun, the cities will be ready to meet emergencies when the great conflict is called off. 
Have the results of the year justified the existence of the leagues? The review of their work leaves no room for doubt that they have. It is not only what the organizations accomplish in any one year, but the accumulative effects of their efforts for a number of years that must be considered when judging the value of their labors.

\title{
SOME TENDENCIES OF RECENT MILK LEGISLATION
}

\author{
BY HARLEAN JAMES \\ Baltimore, $M d$.
}

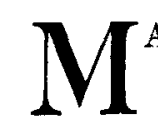

ANY of us can remember a time when, even in our large cities, milk was dipped or poured from cans into receptacles set out by purchasers. In that day the cows usually stood (when they were given shelter from pasture) in a general-purpose barn covered with dust and cob-webs. Cows were seldom groomed. The hired man, in soiled woolen clothes, milked into an open-top milk pail which had been rinsed with cold water from the well and poured the milk into cans which were transported by wagon direct to the consumer. Refrigeration was not dreamed of.

Since that day the bacteriological origins of many diseases have been discovered. Milk, the scientists tell us, is an ideal medium for the rapid multiplication of bacteria. By means of contaminated water used in washing utensils, through the introduction of particles of manure, through the handling of milk by "typhoid-carriers," disease bacteria may reach the trusting consumer by the milk route. Milk has been in the past, and too of ten in the present is, exposed on its journey from cow to consumer to the deadly machinations of the house and barn fly.

The working hours of bacteria, however, are very irregular. A farmer may truly say that he and his wife and seven children have thrived on milk produced in the old way. But city health officials in recent years have realized that they must endeavor to protect the public from the possibility of disease carried by milk.

The first efforts of cities to control their milk supplies were mainly in the direction of preventing adulterations. The time-worn farmer jokes concerning water in the milk reflected an all-too-prevalent custom. The tendency of milk to sour quickly in warm weather brought preservatives into common use. Some of these were distinctly harmful; others, less so, if we may believe certain chemists; but it is now generally against the law to put preservatives of any kind in milk. The federal pure food movement to insure proper labeling also has had its effect in local laws setting up chemical standards for whole milk in order that consumers 